\title{
Heritage of Mongols: The Story of a Russian Orthodox Church in Transbaikalia
}

\author{
Nikolay N. Kradin ${ }^{1,2} \cdot$ Nikolay P. Kradin ${ }^{3}$
}

Published online: 16 August 2018

(C) The Author(s) 2018

\begin{abstract}
The Kondui Palace is the world-famous archaeological site of the Mongolian Empire's period. However, few people know that the ruins of the palace were used for the construction of the Orthodox Virgin church in the Kondui village in the early nineteenth century. This paper describes the construction of the church with regard to studies of the Mongolian palace.
\end{abstract}

Keywords Mongols · Kondui palace · Orthodox architecture - Siberia · Transbaikalia · Chinggis khan

\section{Introduction}

In the vicinity of the Kondui village in Transbaikalia, some $750 \mathrm{~km}$ to the east of Lake Baikal, lies an important archaeological site known as Konduisky gorodok (the town of Kondui). Even though the name became common both in the archaeological literature and among the locals, this place is, of course, no town at all, but an entire palace complex complete with various auxiliary buildings. The number of nomads' tents around it is unknown. It is, perhaps, the number of inhabitants that allows calling Kondui a town. The site itself dates

Nikolay N. Kradin

kradin@mail.ru

Nikolay P. Kradin

n_kradin@mail.ru

1 Laboratory of Archaeology, Ethnology, and Anthropology, Institute of Mongolian, Buddhist, and Tibetan Studies, Siberian Branch of the Russian Academy of Sciences, 6 Sakhyanovoy St, Ulan-Ude 670042, Russia

2 Department of Archaeology, Institute of History, Archaeology and Ethnology, Far East Branch of the Russian Academy of Sciences, 89 Pushkinskaya St, Vladivostok 690001, Russia

3 Department of Architecture and Urban Studies, Pacific State University, 136 Tikhookeanskaya St, Khabarovsk 680035, Russia 
back to the Mongolian Empire. It has been thoroughly investigated and described by archaeologists (Kiselev 1958, 1965; Kradin et al. 2016; Kuznetsov 1925; Steinhardt 1988).

The village of Kondui lies $7 \mathrm{~km}$ to the north of the palace. This article focuses not only on the palace but also on an Orthodox church in the village. The church was named after the Nativity of the Most Holy Mother of God and Holy Martyrs Cyricus and Julietta. The palace and the church are approximately one-hour walk from each other, but the historical periods in which they existed are more than four centuries apart. One might ask what these two objects share in common? Surprisingly, a close mutual relationship characterizes them.

As it turns out, the church was literally built from the ruins of the palace. First, we consider how the church was erected and provide its description. After that, we elaborate on the archaeological discovery of the palace and its study by scholars. In conclusion, we briefly discuss the importance of this church in the history of architecture and archaeology.

\section{The Idol Temple of the Devil}

East Transbaikalia is a territory on the Russian-Mongolian and Russian-Chinese borders. In the eighteenth and nineteenth centuries, it was populated by the Russian Cossacks. They engaged in farming and safeguarded the border. The Kondui village was founded in 1773 as a frontier Cossack post by Cossack Vasily Epov. The territory was suitable for agriculture and craftsmanship. Epov engaged in horse breeding and the rearing of domestic cattle. He got married and had four sons. They followed in his footsteps. It was probably his younger son Semyon who was the first to find a hill with the ruins of the walls and columns in six versts (about seven $\mathrm{km}$ ) to the south of the village of Kondui. Semyon held a rank of uryadnik (Cossack sergeant). Before passing away, Semyon made a will in which he bequeathed his wife and children to build a church in the village (Stukov 1844).

His widow went to the town of Nerchinsk and submitted a request to build a church. Nerchinsk was one of the first Russian towns in this territory, established in 1653. In the late eighteenth century, it was a local administrative center.

According to the archival sources, in October 1804 the Bishop of Irkutsk and Nerchinsk Veniamin sent a report to the Holy Synod requesting the construction of a stone church (temple) in the village of Kondui. In his message, Veniamin wrote, The spiritual board of Nerchinsk sent me a letter of consent of the residents of different social strata of Nerchinsk and Zavodsky settlements, providing the following information. Because the churches are far and it is difficult to conduct church services, these people want to build the stone Cyricus of Holy Mother in Honor of the Nativity with the side-altar of Holy Martyrs Cyricus and Julietta church on the vantage ground (Kondui village).

Veniamin noted that talking with the ecclesiastical authorities, the residents of many villages in the Nerchinsk district complained of the absence of a Christian 
temple. He put it, some settlements were in two hundred versts, and others not nearer than in one hundred versts from the parish churches and, due to such long distance, it is not uncommon that the sick die without due Christian last rites and the infants cannot be baptized, while many Tungus people migrating between the aforesaid settlements agree to take baptism but, as a result of remoteness of churches and priests, remain unbaptized. So this motivated them to build the church in the center for all settlements, the village of Kondui, though the village mentioned above is not very populous for the time being but advantageous due to an abundance of lands suitable for agriculture and haymaking. Besides, here there are rich forest and water resources. The place for construction is very convenient. After the construction of the church, the population in the village will quickly grow. For the initial construction phase, three thousand rubles were raised. Afterward, the residents will help with the additional funds. A sufficient amount of construction materials can be found in the vicinity of the village.

In his report, Bishop Veniamin made it clear that the decision giving permission to build the new church in Kondui was his own, taken without consultation with superiors. Also, he did not coordinate the issue of the allotment of land for the settlers' cemetery and kept the future church officers on the premises with the Irkutsk provincial government on the grounds "that large acres of wasteland exist around there." Understanding that such coordination would be time-consuming, he "dismissed any contacts" (RSHA, f. 796, list 85, 1804, volder 818).

After consideration of the report by Bishop Veniamin, the Holy Synod authorized the construction of the stone nativity church in the village of Kondui by an act issued on December 22, 1804. The church was erected in 1806. The procurement of construction materials and construction of the church were carried out by residents.

As far as the construction materials were concerned, the builders utilized the wreckage of the "Idol temple of the devil."

In this manner, the ruins of the ancient buildings found by Cossack sergeant Semyon Epov near the village were put to use. Epov had begun to excavate a large hill on the plain where the local Cossacks mowed hay. There he had found bricks, stones, adornments, and different ceramic products. This discovery led him to an idea that these artifacts could be used as construction materials for a new church. In all probability, a touchy question arose whether one should use "devilish articles" for the construction of an Orthodox church, but it did not seem to bother the locals. For a charitable deed, any construction materials would do. In the steppe zones of East Mongolia and Transbaikalia finding construction materials, indeed, posed a real problem.

After obtaining a permit, the Cossack carts headed for the large hill and other nearby hills, and the Cossacks began digging out the many bricks, stone bases of columns, and diabolic mugs (with images of dragons and other monsters) and carried them off to the village. The scrap materials were also used to build the foundations of the Cossack houses and, later, for the erection of the Tsugol datsan (lamasery) in the Aga Buryat region. 


\section{The Temple of the Holy Mother}

A raised foreground at the village center was chosen for the construction of the church in 1806 (Figs. 1 and 2). The description said that the temple (with bell tower) was made of stone. There were two altars in it. In the cold room, the altar was named in honor of the Nativity of Mary, while the one in the warm hall honored the Holy Martyrs Cyricus and Julietta. There was a definite shortage of construction materials. For this reason, the altar of the Holy Mother was finished later with nineteenth-century bricks. The entire churchware and icons were provided by the widow Maria. Stefan Plyaskin of Nerchinsk became the first preacher (Stukov 1844).

Having no other archival data on the Kondui church, it is hard to tell what sort of blueprints and drawings the builders used for the construction. On the one hand, we can only assume that virtually any plan could be used as a sample. On the other hand, though, as the analysis of the surviving temple shows, the project was completed by the locals. It may well be that an appointed resident engineer from Nerchinsk or Chita supervised the construction process. It is also hard to say whether any similar temple buildings exist. A review of the plans of a number of churches and graphic and photographic materials regarding Russian templar structures of the seventeenth and eighteenth centuries yielded no significant results. As to the configuration and compositional structure of the plan, we managed to reveal several similar temples (churches) built in the first half of the eighteenth century in the suburbs of Moscow. These are the Spassky church in the Paveltsevo village (1715), the Annunciation (Blagoveshchensky) church in the Salkovo village (1704), the Kazansky church in the Kiyasovo village (1701), and the Kazansky church in the Sukovo village (1745).

Comparing the structural and volume-spatial characteristics of these churches, a certain similarity to the Kondui church appears in only two of them, namely the Spassky church in the Paveltsevo village and the Kazansky church in the Sukovo village (Fig. 3). The church from Sukovo is closer to the Kondui temple in its composition. The same structural system without columns and the volumespatial composition characterizes it. It is also interesting that both temples

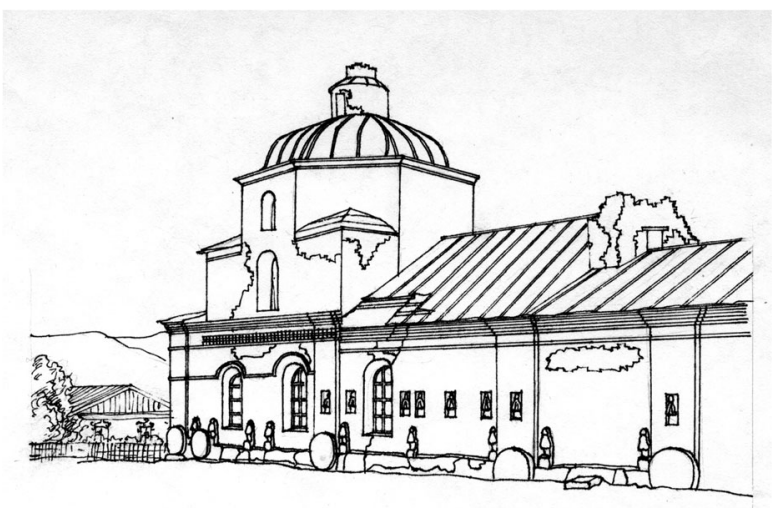

Fig. 1 Orthodox Church after the Nativity of the Most Holy Mother of God and Holy Martyrs Quiricus and Julietta 

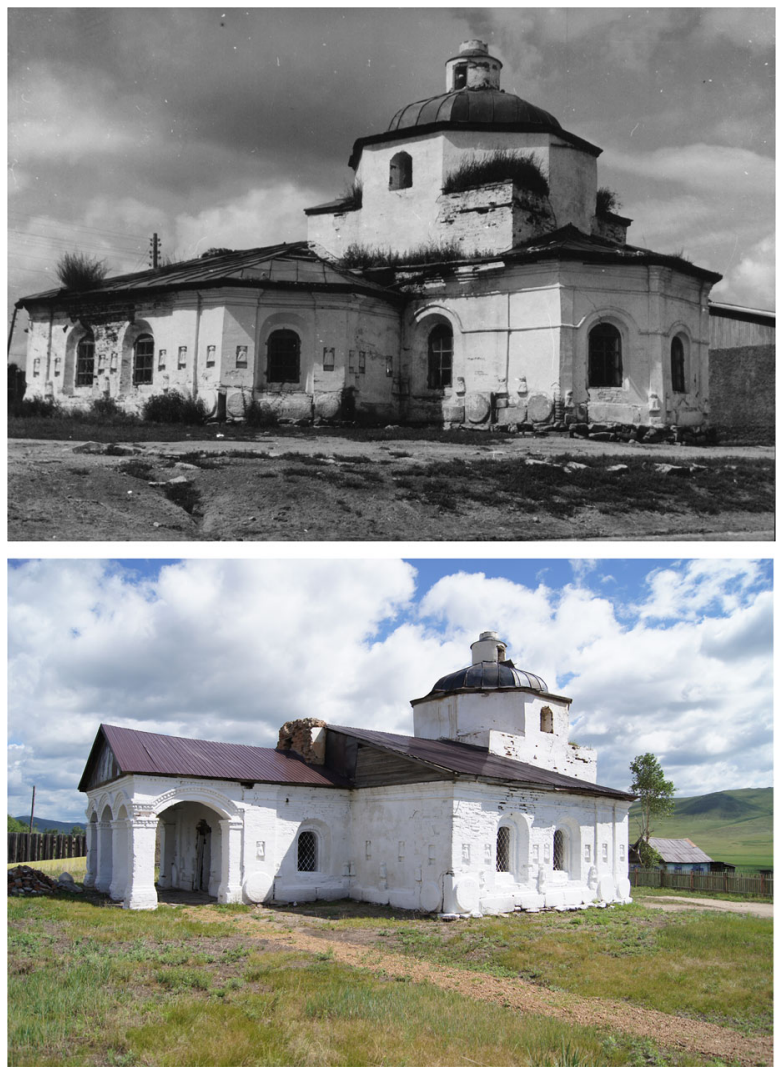

Fig. 2 Ortodox Kondui Church today

display virtually the same external dimensions in plan. The differences are also quite substantial. For instance, in the Kondui Orthodox Virgin Church, the space between the altar and temple volume with three kinds of illumination is divided by one wide archway, while in the Kazansky church there are three archways here. The contours of apses in the temple and side altar of the Kondui church are faceted, while in the Spassky church they are semicircular.

The compositional structure of the church plan is strictly axial: apse, hall of the temple, fratery, and bell tower (Fig. 4). The symmetry of the axis is disturbed by a southward shift of the fratery and by the attachment of the side altar with its apse. Within the temple, the space of the side altar is combined with the fratery and bridged by one barrel arch placed perpendicularly to the axis of the church (west-east). The quadrangular frame of the church has a square footing with the following dimensions (along with the internal walls) $4.6 \times 4.7 \mathrm{~m}$ in plan. The internal space of this part of the church rises and changes into an octagonal structure bridged by the eight-troughed cloistered vault. The walls within the temple are smooth, and the decorative components and traces of iconostasis do not survive. The thickness of the walls made from the stones taken from the ruins of the Kondui town reaches $1 \mathrm{~m}$. From the outside, the wall surfaces are dissected by the alettes corresponding to the divisions of the internal space of the church. 


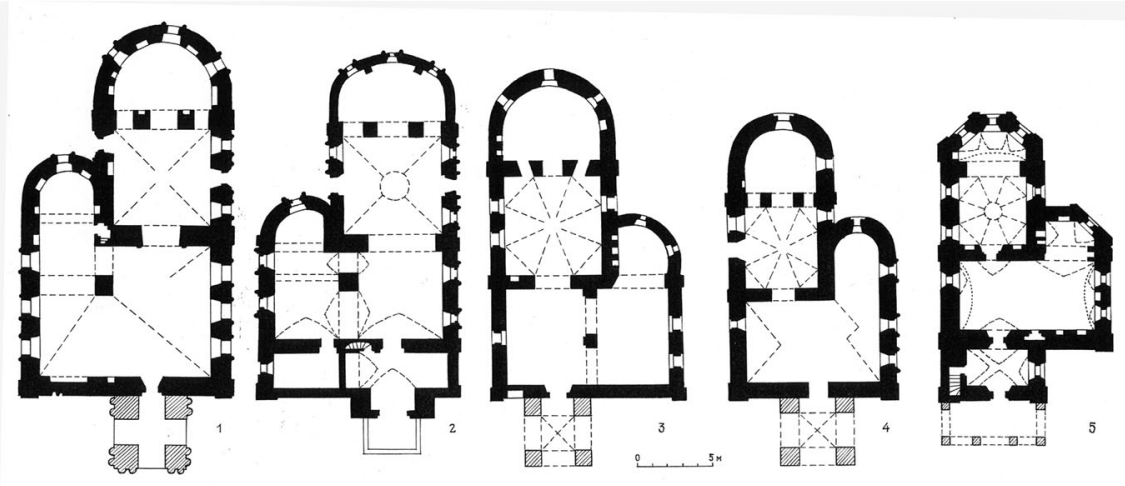

Fig. 3 Charts of similar Churches. 1 - Annunciation church in Salkovo, 1704; 2 - Kazan church in Kiyasovo, 1701; 3 - Saviour church in Peveltsovo, 1715; 4 - Kazan church in Sukovo, 1745; 5 - Holy Mother of God church in Kondui, 1806

As mentioned above, apart from the construction materials (bricks and stones), the decorative fixtures, in particular, the dragon-like sculptures, as well as the bases of columns from the palace and the town ruins, were also used for the construction of the Orthodox Virgin Church. They were mainly used on the temple facades: 19 elements on the north-facing façade, 13 elements on the east-facing one, 18 elements on the south-facing one and 14 elements on the west-facing façade. All of them are positioned in the two rows: a bottom row is on the socle, and a top row is in the individual niches in the middle part of the plane of walls. A total of 34 elements were installed in the bottom over-socle row and four less in the top row (Fig. 5).

Curiously, the bottom chord passes along the entire church perimeter and also embraces the side altar. The elements of the top chord are placed in the form of a semi-ring: beginning with the altar part of the south side altar they pass through the entire side altar, move to the remaining portion of the south-facing façade and, after that, to the west-facing one, while on the north-facing façade they pass only along the fratery wall. Therefore, the top chord is absent in the whole sanctuary, and it is also absent in the north-facing façade of the temple volume. The granite blocks, the bases for the columns of the palace, were installed in the socle. Protruding with circles, they fix the corners of the church volumes and the bases of the pilasters. Only a few blocks were randomly inserted in the socle on purpose, without respect to the corners and pilasters (Fig. 6).

Unfortunately, the cupola crowning the double-deck caisse roulante over the dome does not survive. The bell tower whose remains project above the ridge of the doublepitch roof on the border of the entrance portico and fratery was also destroyed. The portico - consisting of four columns of the rectangular cross-section-was apparently attached at a later point in time. Its somewhat different stylistics and, above all, material confirm this assumption. The portico was entirely lined with bricks. It is even not a portico but a church porch with three archways on the western side and one archway on the northern and southern sides. The thrusts are connected together with the shallow arches, pronounced by triple roll moldings. Over them, the simplistic friso with eave trim was made. The fronton of triangular shape was boarded up. 


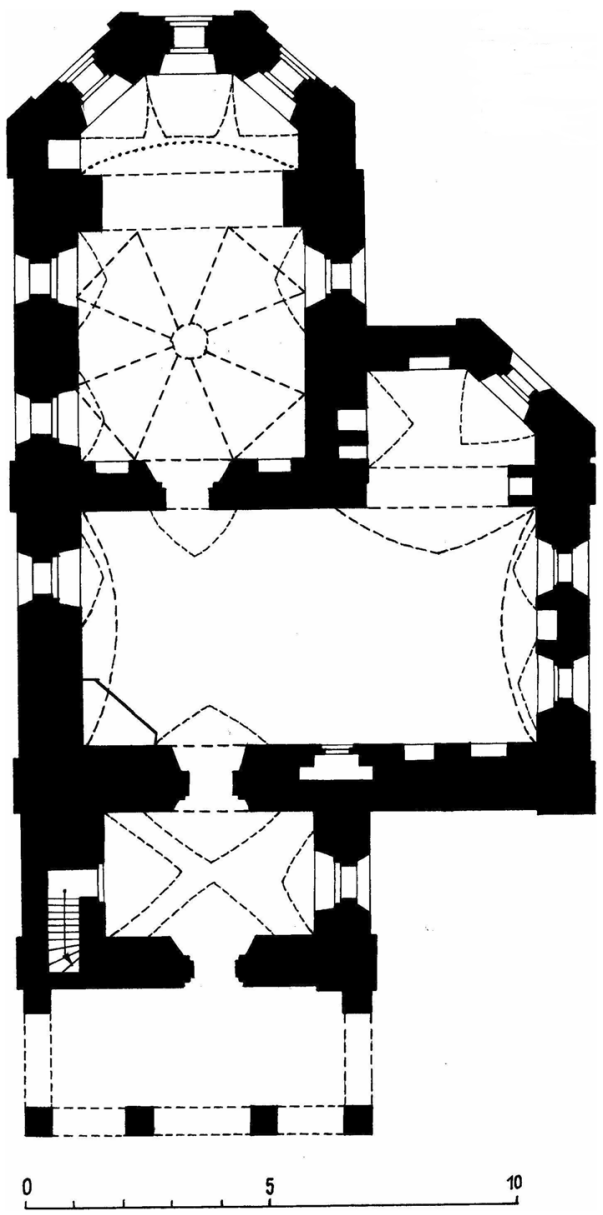

Fig. 4 Cross-section of Kondui Church. 1984

In 1798, well ahead of the church construction, the remains of the palace complex were surveyed by Peter Frolov. He was an engineer, the builder of the first cast-iron railway in Russia, governor of Tomsk in 1822-30 as well as a son of the Russian engineer-inventor Kouzma Frolov from the Urals (Frolov was also the ancestor of Nadezhda Krupskaya, wife of Vladimir Lenin). Peter Frolov made a journey to Transbaikalia, where he visited the ruins of the Kondui palace and made two pencil drawings which are kept in the Saltykov-Shchedrin Public Library, St. Petersburg (Umansky 1960).

In the nineteenth century, the ruins of the palace were described several times by travelers and resident engineers (Parshin 1844; Pavlutsky 1867). One of them, engineer Fyodor Balnauf, authored a love poem Avaan and Gairo. The poem narrates a legend of the young queen who raced off with the lover from the old Crown. This crown had a palace in Kondui. Aleksei Kuznetsov made the fullest description of the Kondui palace. He began to examine the remains of the palace from 1899 but published his book only in the Soviet times (Kuznetsov 1925). Kuznetsov was a man of marked individuality. In his early years, he was charged with the legal cause of the well-known terrorist Sergei 

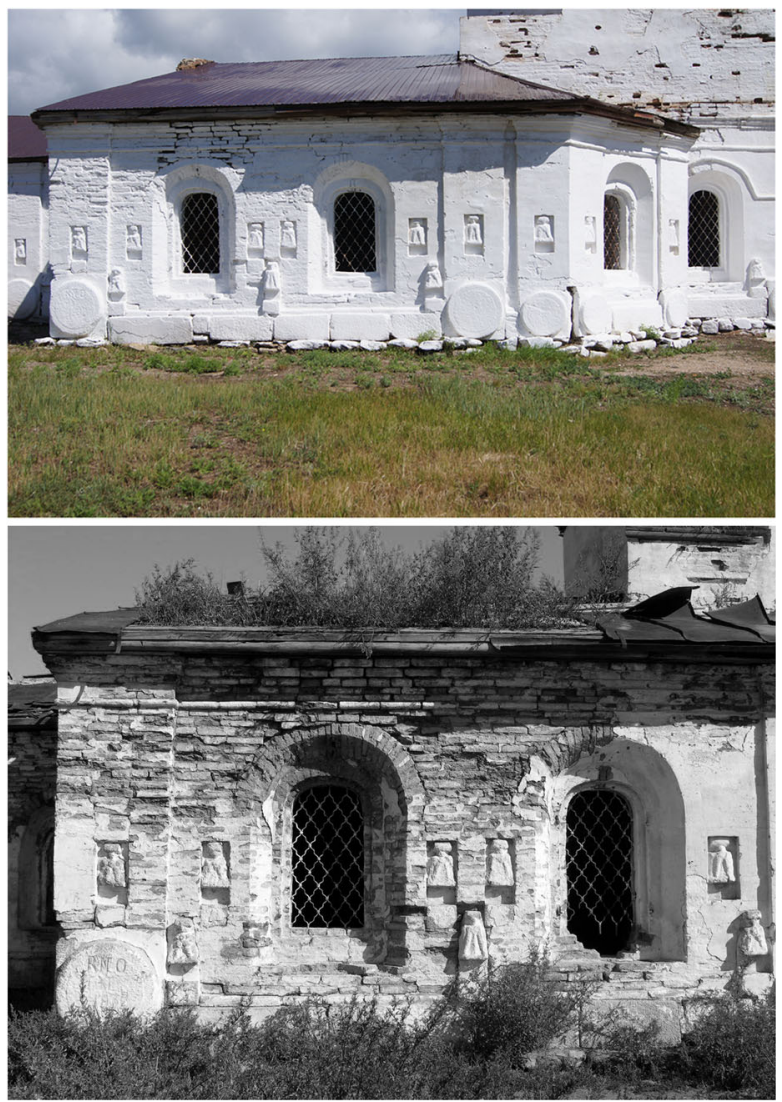

Fig. 5 Kondui Church. Dragon-like and columns foundations

Nechayev and sentenced to hard labor to Siberia. In Siberia, he was actively involved with the enlightenment of the population. He was the founder of two major museums. In 1881, he opened the museum of local lore in Nerchinsk and in 1895, the museum of local lore in Chita. In Transbaikalia, Kuznetsov was actively engaged in archaeology and ethnography and made a significant contribution to the development of education. Simultaneously, he was fully engaged in revolutionary activities. Several times this activity got him in prison. After the Russian revolution in 1917, Kuznetsov became the director of a museum in Chita.

In the Kondui church, 64 sculptures from the palace were embedded into the walls on all sides. These were dragon-like, but none of the Cossacks were aware of it. They believed that these were diabolic figures made by godless people (barbarians). The sculptures were installed not horizontally as in the palace, but vertically. Therefore, the snouts of the dragon-like figures turned out to be mounted into the walls. As a result of multiple white-washings of the church walls, the relief contours were smoothed out. The relief turned into something similar to anthropomorphic figures. Nobody knew about the dragon-like figures and the correct time of their creation (Fig. 7).

What they actually were, became evident only after the archeological excavations of the well-known Soviet archeologist Sergei Kiselev. He excavated the capital of the 


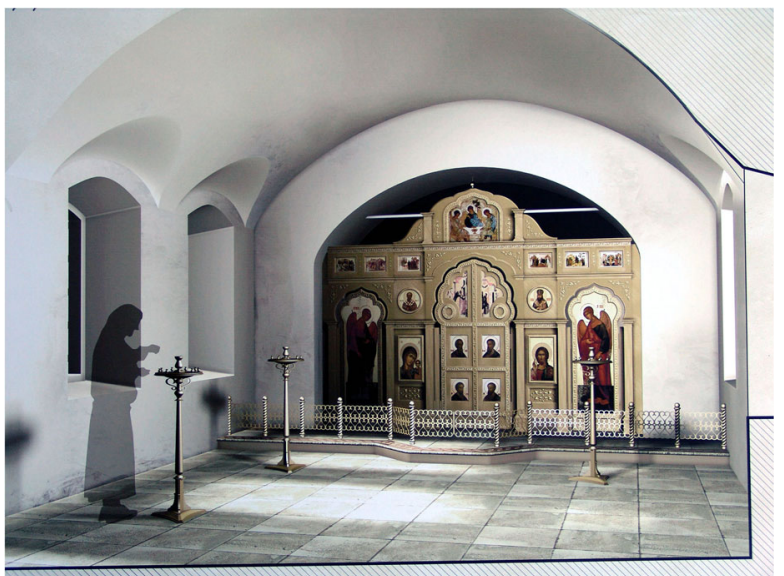

Fig. 6 Reconstruction by altar

Mongolian Empire Karakorum in 1948-49 (Kiselev 1965). In 1957-58, the excavations of Kondui were carried out under his supervision (Fig. 8). The largest platform the palace - was fully excavated. Of particular value here is that the central portion of the complex was revealed and this is where the granite bases of the columns remained in their former positions. Unfortunately, a few dozen of the same bases on the southern and northern sides of the palace were removed for the construction of the Kondui Nativity of the Most Holy Mother of God Church, for the repair of the Tsugol Datsan, and for construction needs of the Kondui residents. However, despite such losses, the excavations assisted in ascertaining the configuration of the whole complex and its palace. The granite dragon-like figures which ornamented the palace were also found. It was Kiselev who correctly dated this palace and numerous artifacts from the times of the Mongolian Empire (Kiselev 1965: 323-369).

What did the Kondui palace complex look like? The palace building rested on a two $\mathrm{m}$ cruciform clay platform. The platform was paved with brick floor. It had five brick entrance ramps: two in the east and two in the west, and one principal entrance in the south. There was no entrance ramp on the northern side. The similar planigraphic structure combines the principles of spatial organization of the Chinese (and indirectly Jurchen) architects and traditions of the spatial organization of the Mongolian-speaking nomads (one exits from a yurt on the southern side while the northern side is the most prominent part of the yurt and hence taboo).

The column bases remaining in their places and their remains give grounds for a trustworthy presumption about the arrangement of the colonnade of three pavilions. Based on the remaining fragments unearthed during the excavations, the entrance ramps to the lower and top verandas of the palace are also visible. The particular problems related to the question of the arrangement of the granite dragon-like habitacles along the veranda (terrace) outline do not appear. By the way, the verandas (terraces) proved to be the most researched parts of the complex. Kiselev (1958: 115) wrote about them, "The verandas (terraces) of the Kondui palace were ornamented by the wooden balustrade coated with red lacquer, the posts of which were fixed in the square grooves of the special granite slabs. Besides, along with the lower veranda (terrace), the granite sculptures in the form 


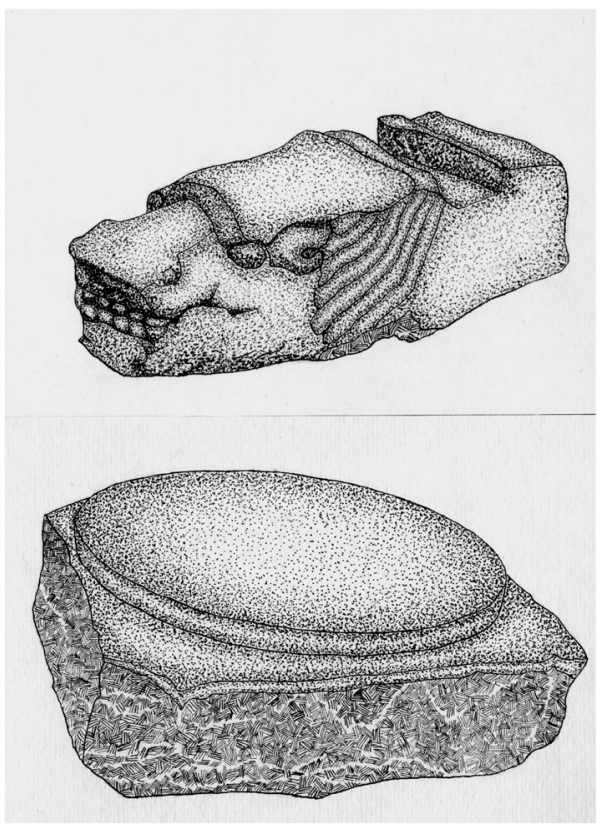

Fig. 7 Kondui Church. Dragon-like figures and column foundation

of the snouts of the dragon-like figures, boars, and animals with horns of fallow deer were imbedded."

The similar architectural ideas are also present in the Palace city of Dadu, the Great Capital of the Yuan dynasty. So, in the Palace city of Dadu, three terraces were constructed and, there, the sculptures were inserted not only along the outline of the lower terrace but also in all three terraces. One should note that the cruciform shape was also not unique at that time (Gaohua Chen 2015: 43).

Within the Kondui palace, there were 37 stone bases for wooden columns. The building consisted of several parts: an entrance room, walk-through corridors, an audience room, and private rooms or utility spaces. From above, the palace was covered with the green-glazed tile and ornamented by snapdragons. Images of animals and fantastic beings also ornamented the walls of the palace.

The system of pavilions inscribed into the regular polygon surrounded the palace (Fig. 9). The pavilions arranged in parallel with the principal axis framed the courtyard from the right and left. Two buildings were situated on both sides, southwest and southeast of the palace. In the north, there were three buildings. Also, a number of structures breaking the strict symmetry of the complex existed next to the palace. Quite possibly, they were erected later than the principal components of the palace complex. In the south, there was the main entrance gate. The gate, palace, and one of the central northern pavilions were symmetrically located along the north-south axis. There were no other structures south of the palace. In essence, such organization of space entirely copied the principles of the arrangement of the yurts (pastoral tents) in a Mongolian nomadic camp (Lbova and Vasil'eva 1992: 145-146).

The planning of the palace complex followed the principle of deep-spatial composition with the well-pronounced symmetry axis. On the northern side, three pavilions 


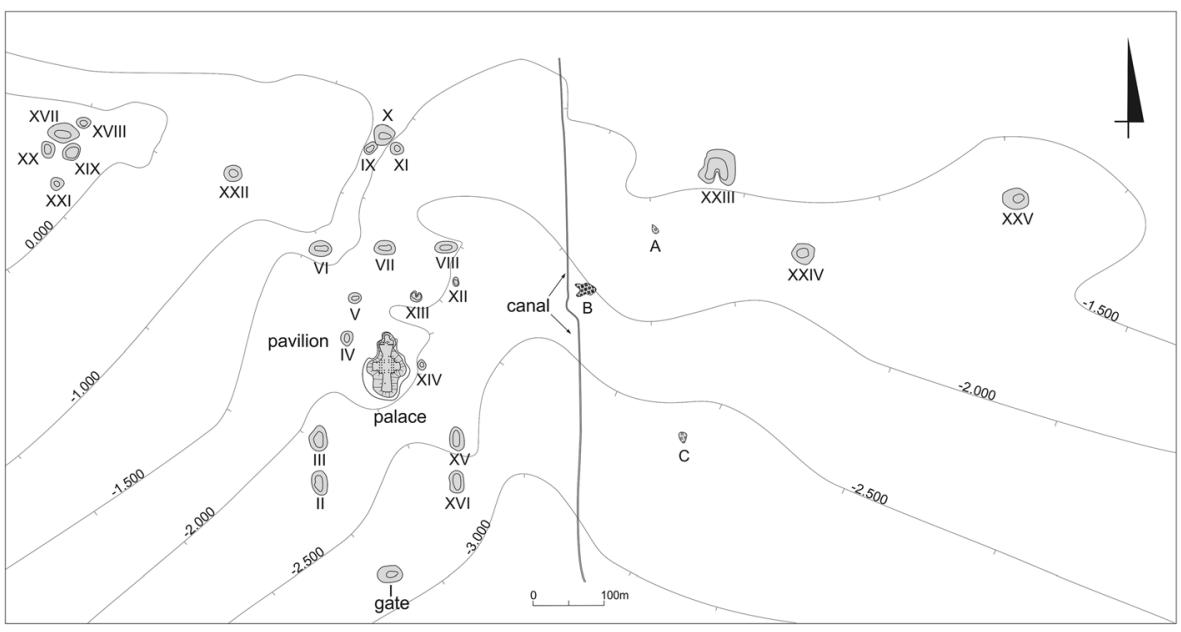

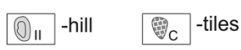

Fig. 8 Map of archaeological site Kondui Palace

placed in a line perpendicular to the major axis framed the palace complex. Farther, at a distance of about $100 \mathrm{~m}$, encircling the axis, stood a rather small residential complex consisting of several structures and symmetrical in its composition. Several similar complexes in the form of hills survived on the eastern side of the palace complex. These were probably the houses of the Mongolian elite or persons meeting the requirements of the inhabitants of the palace. About three $\mathrm{km}$ to the east of the palace, were the remains of tile kilns as detected by geophysical survey.

The excavations revealed that the bases of the columns remained in their places. This information, coupled with the contours of the platform in the center of the palace allow, with a certain amount of confidence, a hypothetical reconstruction of its volumetric and spatial composition. Two Russian historical architects also reconstructed the appearance of the palace (Minert 1985; Tkachev 2009).

In 2015-16 we carried out the study of the northwest pavilion of the Kondui palace. We managed to excavate the palace's pavilion with the dimensions about $23 \times 8 \mathrm{~m}$ stretched by its long side along the west-east line. A well-preserved brick rampant with an entrance was adjacent to the palace from the south. Inside the long wall and on the corners of the structure there were stone bases of the subquadratic form. The floor was lined with bricks. The building had a tiled roof. We found many tile fragments covered with green and yellow glaze and one fragment of an end plate. The ridge cappings were ornamented by the sculptural images of dragon-like beings. The construction materials - bricks, tile, stone bases - are similar to those found on the site of the central building. However, the building was not as majestic as the palace. Since we did not find any remains of the heating system in the building, we assumed that it was a summer pavilion. As to the artifacts, we found nails, grindstone, stacks of chips, glazed and porcelain ware as well as the bones of domestic animals.

How and when was this palace built? We know that after Chinggis Khan had established the empire, he spent most of the time in military campaigns. Nevertheless, 


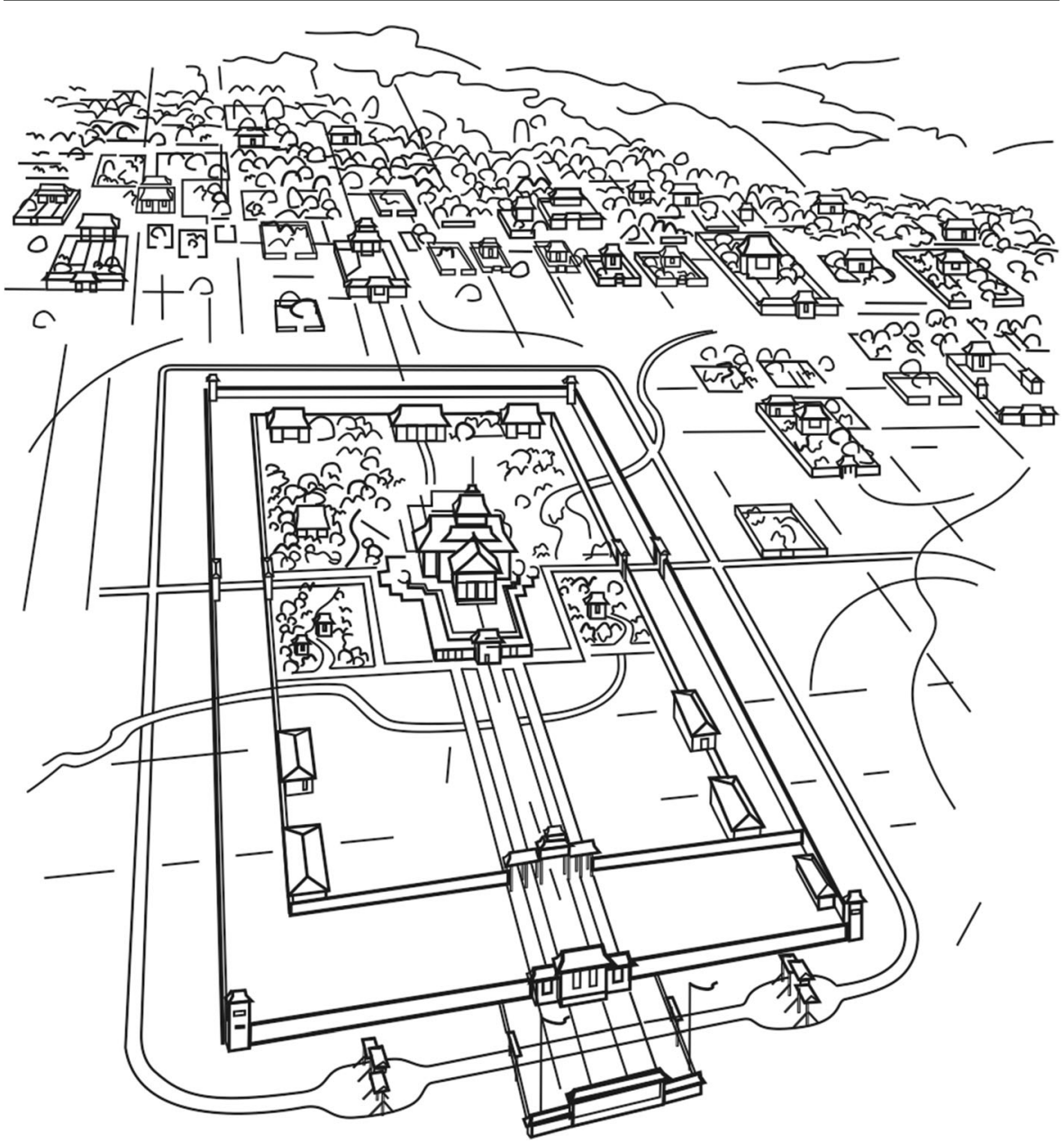

Fig. 9 Reconstruction of Kondui Palace. After L. Minert

in 1220 , he decided to build a capital in the Orkhon River valley. The construction of the town began after his death in 1235 . They first built the khan's palace and walls and then other palaces and houses for the Mongolian elite.

In East Mongolia, a town without walls existed near the Herlen River. Its contemporary name is Avraga (Shiraishi 2006). There is a large town of Heishantou with magnificent ramparts (walls) and two inner palaces in Hailar, Inner Mongolia. In Transbaikalia, there is the town of Khirkhira. It was also without walls but with streets and a fortress-palace. This town (site) was excavated by Kiselev (1965: 28-58) and other archaeologists (Artemjev 2005; Kradin et al. 2016). Khirkhira is situated $61.7 \mathrm{~km}$ east of the Kondui palace. Apart from towns, the Mongols erected standalone palaces in the steppe. The Alestui palace is located near Khirkhira (Kradin et al. 2012). The Narsatui palace is in Buryatia (Danilov, 2004).

It is noteworthy that the territory of East Mongolia and Transbaikalia belonged to Chinggis Khan's brothers - Tämügä Otchigin and Qasar or Khasar. Both these 
historical figures played the crucial roles in the history of the Mongolian Heartland (Rashid ad-Din 1998: 129-132). The Heishantou site in Inner Mongolia is considered to be the residency of Khasar. It is a massive fortress surrounded by the high earthwork. Khirkhira is considered to be the residency of Yesünggü - son of Khasar (Kradin 2018). It is not known who lived in the Kondui palace. Most likely, it was a man of the highest status. We can judge by the dragon-like figures ornamenting the palace. A dragon is emblematic of the imperial power in China. For this reason, we assume this was the palace of one of Chinggis Khan's kin.

\section{Conclusion}

The Kondui Orthodox Church is at the same time the archaeological site of the period of the Mongolian Empire and the monument of the Russian architecture. During the Soviet period, the church was closed down and gradually wrecked as cattle went in and out of it. In summer, it was the favorite cooling place for horses and cows. As a result, the church gradually filled up with manure. In the postSoviet era, as a result of the economic crisis, the village declined. It was mostly populated by the elderly. The young people strove to move to urban areas after graduation. However, thanks to the efforts of the residents, the church was cleaned up and the roof repaired. However, the repair and reconstruction demand a good deal of money. Two years ago, the governor of Transbaikalia came to the excavations. He was then a well-educated businessman who observed the palace and church with great interest and promised to help with the reconstruction of the Orthodox Temple. However, several months later he was dismissed. Since then, the hope of a quick reconditioning of the monument died again.

One of the first surveyors of the Kondui palace, Aleksey Kuznetsov (1925: 14) wrote that the houses of Cossacks and stone church "are characterized by the fairly graceless architecture," though they were on a beautiful elevated place. Perhaps he was bowled over by the coarse setting, curved walls, absence of proportions in the volumes and divisions, and stumpiness of the church. All of this is indeed present. At the same time, the contrast of the low space of the entry section and fratery with the high and light church space can be viewed as an interesting composition. However, the core value and originality of the Nativity Church lie in the fact that is was built from the ruins of the medieval palace of the Mongolian khan. The decorative fixtures of the palace surviving in the walls of the church today are of considerable scientific and artistic value.

Using the decorative elements of the Mongolian palace alien to Russian medieval culture, the builders of the church gave no thought about how it would look. Though, perhaps, understanding this extraneity they immured the images of dragons in the walls and turned the habitacles from the decorative elements into simple construction materials preferring to show the surface finish of the backside of blocks rather than the front-face plastics. It was only the accidental anthropomorphic resemblance of the picture of this side that launched their restoration. 
Open Access This article is distributed under the terms of the Creative Commons Attribution 4.0 International License (http://creativecommons.org/licenses/by/4.0/), which permits unrestricted use, distribution, and reproduction in any medium, provided you give appropriate credit to the original author(s) and the source, provide a link to the Creative Commons license, and indicate if changes were made.

\section{References}

Artemjev, A. R. (2005). Novye issledovaniia drevnemongolskikh gorodov Vostochnogo Zabaikalya [new studies of the ancient Mongolian towns in eastern Transbaikalia]. Vestnik Dalnevostochnogo Otdeleniya Rossiyskoy Akademii Nauk 2: 3-18.

Danilov, S. V. (2004). Goroda v kochevykh obshchestvakh Centralnoy Azii [Towns in the Nomadic Societies of Inner Asia]. Buryatian Scientific Center of the Siberian Branch of the Russian Academy of Sciences Press, Ulan-Ude.

Chen, G. (2015). The Capital of the Yuan Dynasty. Silk road press, Honolulu.

Kiselev, S. V. (1958). Drevnie goroda Zabaikalia [ancient towns of the east Baikal region]. Sovetskaia arkheologiia 4: 107-119.

Kiselev, S. V. ed. (1965). Drevnemongolskie goroda [Ancient Mongolian Towns]. Nauka, Moscow.

Kradin, N. N. (2018). Who was a builder of Mongolian towns in Transbaikalia? Golden Horde Review 6(2): $224-237$.

Kradin, N. N., Sarantseva, S. E., Kharinsky, A. V., and Kovychev, E. V. (2012). Issledovanie Srednevekovoy Mongolskoy Usadby Alestui V Zabaikalye [the Study of Mediaeval Mongolian Estate Alestui in Transbaikalia]. In Tumen, D. ed., Ancient Cultures of Mongolia and Baikal Siberia. Vol. 2. Mongolian State University, Ulaanbaatar, pp. 381-387.

Kradin, N. N., Baksheeva, S. E., Kharinsky, A. V., Kovychev, E. V., and Prokopets, S. D. (2016). Arkheologiia Chingis-khana v Mongolii i Zabaikalye [Chinggis Khan Archaeology in Mongolia and Transbailakia]. Stratum Plus 6: 17-43.

Kuznetsov, A. K. (1925). Razvaliny Konduiskogo gorodka i ego okrestnosti [Ruins of the Kondui Town and this Vicinity]. Kniznoe delo, Vladivostok.

Lbova, L. V., and Vasil'eva, I. G. (1992). K Voprosy O Razvitii Printsipov Planirovochnoy Structury Drevnemongolskikh Gorodov [on the Question of Development of the Mongolian Ancient Town Planning Structure]. In Konovalov, P. B. ed., Arkheologicheskie pamiatniki epokhi srednevekovia v Buryatii i Mongolii [Archaeological Sites of the Mediaeval Period in Buryatia and Mongolia]. Nauka, Novosibirsk, pp. 145-160.

Minert, L. K. (1985). Drevneishie Pamiatniko Mongolskogo Monumentalnogo Zodchestva [Ancient Sites of Mongolian Monumental Architecture]. In Derevyanko, A. P. (ed.), Drevnie kultury mongolii [Ancient Cultures of Mongolia]. Nauka, Novosibirsk, pp. 184-209.

Parshin, V. (1844). Poezdka v Zabaikalskiy kray [Travel to Transbaikal area]. Vol. 1. Tipografiia Nikolay Stepanova, Moscow.

Pavlutsky, A. (1867). Kratkoe opisanie tak nazyvaemykhchudskikh drevnostey, imeiushikhsia okolo klichkinskogo serebro-svintsovogo rudnika s ukazaniem nakhozdeniia $\mathrm{v}$ nikh i v drugikh mestakh nerchinskogo gornogo raiona [A brief description of the so-called Chudskie antiquities from the area Klichkin silver-lead delf of the Nerchinsk mountainous district]. Zapiski Sibirskogo otdela Imperatorskogo Russkogo Geograficheskogo obshchestva [Notes of the Siberian Department of the Imperial Russian Geographical Society], Vol. IX-X, pp. 475-507. Printing Office of the Military District Staff, Irkutsk.

Rashid ad-Din (1998-1999). Jami u't-tawarikh, A Compendium of Chronicles: a History of the Mongols, Translated by W. M. Thackston. Vol. 1-3. Harvard University Press, Cambridge, Mass.

Shiraishi, N. (2006). Avraga Site: the 'Great Ordu' of Genghis Khan. In Konaroff, L. (ed.), Beyond the Legacy of Genghis Khan. Brill, Leiden and Boston, pp. 83-93.

Steinhardt, N. (1988). Imperial architecture along the Mongolian road to Dadu. Arts Orientalis 18: 59-93.

Stukov, P. (1844). Izvlecheniia iz tserkovnoy letopisi Konduiskoy Bogoroditse-Rozdestvernskoy tserkvi [extraction from the church chronicle of the Kondui church of the virgin and the Christmas]. Pribavleniie $\mathrm{k}$ Irkutskim eparkhialnym vedomostiam 45(November 10): 501-513.

Tkachev, V. N. (2009). Istoriia mongolskoy arkhitektury [History of Mongolian Architecture]. ASV Press, Moscow.

Umansky, A. (1960). O sudbe sobraniy P.K. Frolova [on the fate of manuscripts of P.K.Frolov]. Altai 14(1): $114-117$. 